\title{
LOYALTY PROGRAMS AND HOW THEY CAN BENEFIT RETAILERS THROUGH CUSTOMER KNOWLEDGE
}

Steve Worthington, Monash University, Australia

\begin{abstract}
This paper reports on research carried out in Australia into attitudes and behaviours of consumers who hold and use loyalty cards, issued by major retail groups. In addition to asking which cards were held; how often they were used and what the value of the rewards were that card holders redeemed, the research investigated attitudes towards the privacy of the information gained by the retailer, from both the application for and subsequent use of the loyalty card. Card holder attitudes were also sought as to the aggregation of loyalty card data and its subsequent sale back to the retailers' suppliers and hence this being an income stream for the retailer who operates the loyalty program.
\end{abstract}

